
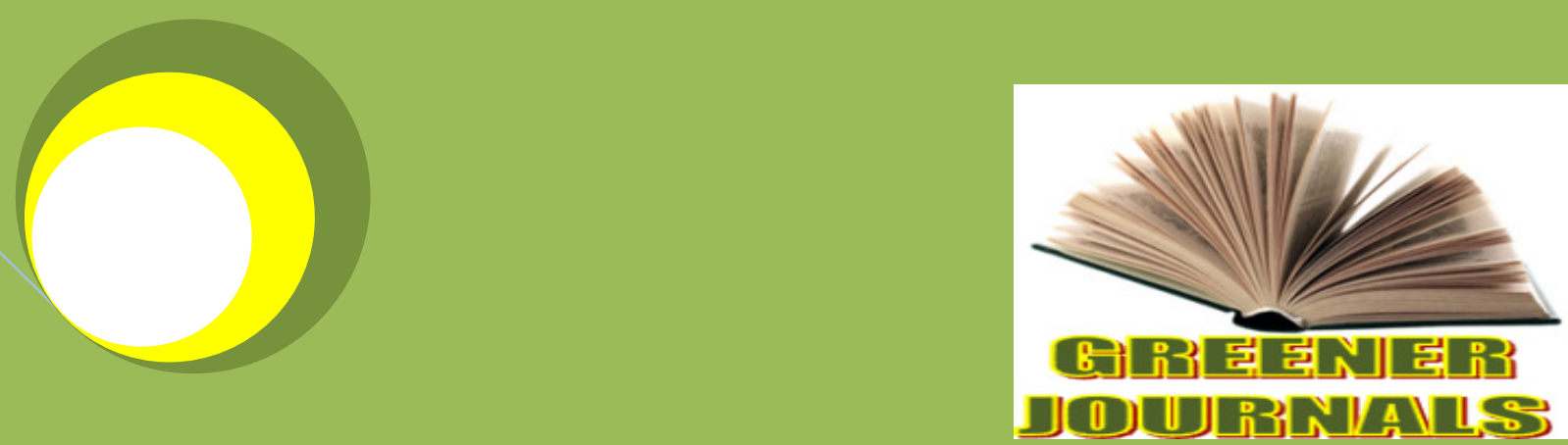

Greeneri Journal of Biólogical Sciences ISSN: 2276-7762 ICV 2012: 5.99

The Effect of Soil and Foliar Fertilization with Iron on Yield and Leaf Chemical Composition of Four Spotted Bean Cultivars in a Calcareous Soil By

Elham Jozedaemi Ahmad Golchin Ghassem Habibi Bibalani 


\title{
The Effect of Soil and Foliar Fertilization with Iron on Yield and Leaf Chemical Composition of Four Spotted Bean Cultivars in a Calcareous Soil
}

\section{Elham Jozedaemi ${ }^{1}$, Ahmad Golchin ${ }^{2}$, Ghassem Habibi Bibalani ${ }^{\star 3}$}

\author{
${ }^{1,2}$ University of Zanjan, Iran. \\ ${ }^{3}$ Departement of Forestry, Shabestar branch, Islamic Azad University, Shabestar, Iran. \\ Emails: 1jozdaemi2012@yahoo.com, ²agolchin2011@yahoo.com \\ *Corresponding Author’s Email: habibibibalani@gmail.com
}

\begin{abstract}
Legumes are one of the main protein sources for human beings and animals. Bean by $20-25 \%$ protein, $55-56 \%$ carbohydrates and $1-5 \%$ lipid plays a basic rule in the nutrition of poor nations. So the increase of yield and quality of bean can be an efficient way for reduction of protein loss in the developing countries. One of the efficient factors in reduction of bean yield and quality in the calcareous soils is lack of iron. High reaction and lime amount and extra bicarbonate of calcareous soils cause leaves chlorosis which reduces growth, yield and quality of bean. In the calcareous soils, absorption of less application elements especially iron in the majority of agricultural products in the bean farming which is sensitive to iron lack encountered with difficulty and its lack is clearly observable. According to farming observations, various type of bean have different potentials from the yield view spotted and there is probability that they have different reaction towards the iron lack, so it is necessary to study in this ground in order to determine the reaction of these figures to iron in various fertilizers. In this regard and in order to improve, bean products quality and increase the yield level of this product to the most probable level, it is necessary to investigate the effect of sources fertilizer methods (soil consume- sparing) on the yield and the quality of this product. In order to inspect the number, sources and various methods of iron fertilizer consuming on micro elements and chemical compound, variants kinds of spotted bean in a limy soil, a green hones trial by 44 treatments and 3 iterates it erases in the factorial form and in the form of complete incidental sign in the zanjan agriculture university of Iran were implemented. In this testing, the consumption of sulphoric acid in watering $(2 \mathrm{~g} / \mathrm{L}), 4 \mathrm{~g} / \mathrm{L})$, soil application of Ferrous sulfate (25 mg/ in each kilogram soli), $50 \mathrm{mg} /$ in each kilogram soli), soil application of $\mathrm{Fe}$ EDTA(3 mg/in each kilogram soli), $6 \mathrm{mg} /$ in each kilogram soli), spraying Ferrous sulfate by density of 2 and $4 \mathrm{~g} / \mathrm{L}$ and spraying Fe- EDTA by density of 1 and $2 \mathrm{~g} / \mathrm{L}$ are considered as iron treatments. By the way an evidence cure is also performed on four types of the spotted bean including Talash, khomein, $\cos 16$ and Local. The result of analysis of the data variance Clemton started that the types Talash and khomein were superior to other kinds from the yield of the seed weight of 100 seeds, numbers of the seeds in the sheath viewpoint. The Local and Talash beans were preferred to other kinds. The treatment of sulphoric acid application in irrigation water $(4 \mathrm{~g} / \mathrm{L})$ has the higher level of average compared to other treatments of iron. The treatment of sulphoric acid application in irrigation water causes the increase of manganese, zinc and copper of the leaves in the spotted bean types.
\end{abstract}

Keywords: Spotted bean types, Iron fertilizers, sulphoric acid, Yield, chemical composition.

\section{INTRODUCTION}

Grains are from the legumes (papilanaceae) family including 750 genus and 20000 species. Legumes are the most important agriculture products after wheat and rice which are consumed by the people of the word and supply a major part of their requirement proteins. In many countries situated in arid and semi-arid regions such as Iran, soils are mostly lime-rich, light- to medium-textured and of low organic matter concentration, resulting in an inadequate nutrient supply (Shadkami-Til, 2013c; Javanmiri Pour et al., 2013). Calcareous soils are defined as soils containing sufficient $\mathrm{CaCO}_{3}$ and $\mathrm{MgCO}_{3}$ to effervesce visibly when treated with a strong acid (Soil Science Society of America, 1997). Alkaline and hard irrigation waters are difficult to manage due to its high contents of bicarbonate, $\mathrm{Ca}$ and $\mathrm{Mg}$ which easily create insoluble compounds causing clogging of the irrigation system. Insoluble $\mathrm{Ca}$ and $\mathrm{Mg}$ compounds will not be formed if $\mathrm{pH}$ of irrigation water is kept continuously on the acidic side. Therefore farmers normally add acids to irrigation water in order to reduce water $\mathrm{pH}$. This involves additional treatment with hazardous liquid acids which are difficult to handle and store. In addition, the bicarbonate ion can be toxic to plants, but more importantly, it interferes with other nutrients and makes them less available to plants (Patricia et al., 2009). Soil acidification sometimes is necessary for optimum plant growth. Soil acidification is best performed prior to planting; it is much more difficult in the established planting of the solubility 
of metallic micronutrients such as iron(Fe), zinc( $\mathrm{Zn})$, and manganese $(\mathrm{Mn})$ in soil solution because it decreases rapidly as soil pH increases, making these elements less available to plants (Horneck and Abak, 2004; Emadi et al., 2012). Soil application of $\mathrm{H}_{2} \mathrm{SO}_{4}$ has been shown to increase Fe availability, theory eliminating chlorosis in sorghum and to increase $\mathrm{P}$ availability in some calcareous soils. Available information suggests that application of $\mathrm{H}_{2} \mathrm{SO}_{4}$ in irrigation water is relatively ineffective for evoking a nutritional response in crops. Iron plays essential roles in the metabolism of chlorophylls. External application of Fe increased photosynthesis, net assimilation and relative growth in seawater-stressed rice (Sultana et al., 2001). This is especially true for soils of high pH where equilibrium conditions favor the oxidation of plant-available $\mathrm{Fe}+2$ to unavailable $\mathrm{Fe}+3$. Plant yield on many soils is, therefore, limited by poor Fe availability, rather than a low Fe content in the soil. Also Fe leaching is the main pathway for Fe loss in coarse-textured soil with high $\mathrm{pH}$, while excessive $\mathrm{Fe}$ uptake was the main pathway for $\mathrm{Fe}$ loss in clay-textured and acid soil. Application of $\mathrm{Zn}$ or Fe has been reported to have significant positive effects, in most cases, on growth measurements and chemical composition of safflower (Lewis and McFarlane, 1986), wheat (Lu et al., 2004), common bean (Fernandez et al., 2007) and rice (Wissuwa et al., 2008). Iron deficiency is quite commonly observed in calcareous soils in all the important field crops. Deficiency of Fe manifest into yellowish inter-venal paling of younger leaves (commonly referred as iron chlorosis). In general, the plants are prone to iron deficiency in alkaline, calcareous, coarse textured, eroded and low organic matter containing cold region soils. Recent research has shown that a small amount of nutrients, particularly $\mathrm{Zn}, \mathrm{Fe}$ and $\mathrm{Mn}$ applied by foliar spraying increases significantly the yield of crops (Sarkar et al., 2007; Wissuwa et al., 2008). Among the micronutrients, Fe nutrition can affect the susceptibility of plants to drought stress (Sultana et al., 2001; Khan et al., 2003; Cakmak, 2008). Further, application of iron salts to soils recovers plants from iron deficiency and compensates for the loss in the yield (Singh et al., 1995). Seed coating with Fe-EDDHA has also been successfully used and shown to increase seed yields (Wiersma, 2005; Penas et al., 1990; Karkosh et al., 1988; Shadkami-Til, 2013a; Shadkami-Til, 2013b). In contrast, Goos and Johnson (2000) did not observe yield increase with Fe-EDDHA seed treatment. However, to the best of our knowledge, information regarding application method efficiency of iron on the growth and development of bean is not available. Therefore, the purpose of this study is to understand whether application of Fe as foliar application is better than soil application.

\section{MATERIALS AND METHODS}

The chosen soil for complementing this study showed the low level of iron absorption. So the samples were provided from the Zanjan University by composed and from the ground level of the soil (0-20 centimeters). The chosen soil passed through a millimeter sieve. The results of the applied soil in this test are shown in table1.

\begin{tabular}{rrrrrrrr}
\hline $\mathrm{Cu}$ & $\mathrm{Zn}$ & & $\mathrm{Mn}$ & $\mathrm{Fe}$ & $\mathrm{K}$ & $\mathrm{P}$ & \\
\hline & & & & & & & $\mathrm{Mg} / \mathrm{kg}$ \\
\hline & & 2.02 & 1.22 & 0.68 & 490 & 2.5 \\
\hline
\end{tabular}

\begin{tabular}{|c|c|c|c|c|}
\hline Soil texture & $\begin{array}{l}\text { Organic carbon } \\
\text { percentage }\end{array}$ & $\mathrm{pH}$ & $\left(\frac{d s}{m}\right)$ & $\begin{array}{r}\text { saturation } \\
\text { percentage }\end{array}$ \\
\hline Ioam & 1.14 & & 7.67 & 1.27 \\
\hline
\end{tabular}

In order to study the various methods for removing the iron loss in bean and the effect these methods has on the bean operation on calcareous soil trail 44 treatment and 3 iterate in factorial form and in quietly incidental frame at the green house were implemented. In this test sulphoric acid in irrigation water ( 2 and $4 \mathrm{~g} / \mathrm{L}$ ), soil application of Ferrous sulfate ( 75 and $150 \mathrm{~kg} / \mathrm{h}$ ), soil application of Fe-EDDHA ( 3 and $6 \mathrm{mg} / \mathrm{kg}$ ) Ferrous sulfate, spray by density (2 and $4 \mathrm{~g} / \mathrm{L}$ ) and Fe- EDTA , spray with (1 and $2 \mathrm{~g} / \mathrm{L}$ ) are included. There was also an evidence treatment (zero level). This test had 44 treatment which were implemented in the 3 iterates and there were 132 trill Crete totally. Exertion of thial treatments was performed in the plastic pots soil and there was $3 \mathrm{~kg}$ soil for each pot. The exertion of sulphoric acid treatment was included in the watering stage and it was used by the water. $\mathrm{pH}$ of watering reduced from 7.3 to 1.701 and 1.90 respectively with ( 2 and $4 \mathrm{~g} / \mathrm{L}$ ) density. Ferrous sulfate cure and Fe-EDDHA dissolved in distilled water and equally sprayed and added in the pots soil. Iron spraying with Fe- EDTA and Ferrous sulfate tried primarily out of the trail design area on the bean leaves and after assuring the luck of related crates dry matter in two stages, it exerted for the trail beans in 18 days intervals before their blooming. The first stage of spraying performed at 10th of April so that the plant is moisture completely and the second stage was implemented after 15 days. Spraying performed at the evening, one hour before sunset in the weather without precipitation and wind. Beans seeds contained four types of khomein; Talash, Local and COS 16 supplied from Khodabandeh Township and cultivated on March 6, 1999. In each pot 3 bean seeds are cultured in $5 \mathrm{~cm}$ depth to the soil level and they are watered after culturing. The consumed amount of water used at the limit can reach the soil moisture up to the field capacity. Watering $\mathrm{pH}$ reduced from 7.3 to 1.70 and 1.90 after adding sulphoric acid with (2 and $4 \mathrm{~g} / \mathrm{L}$ ) density, determination of yield and its 
operation (contain weight of 100 seeds, number of sheaths in one bush, and the number of seed, in a sheath) is accomplished. Elements with less application in clouding zinc, iron, manganese and copper were measured by using of atomic absorption device.

\section{RESULTS AND DISCUSSION}

\section{Yield}

Results obtained from the data variance analysis table demonstrates that the effect of types, sources and various ways of iron fertilizer consumption on the yield property, weight of 100 seeds, numbers of the seeds in the bush and the numbers of seeds in the sheath by $\% 1$ probability level is meaningful (Table 2).

Table 2: Results of variance analysis of sources effect and various ways of iron fertilizer consumption on the yield and operation elements on the spotted beans types.

\begin{tabular}{|c|c|c|c|c|c|}
\hline \multicolumn{6}{|c|}{ The auarage of squares } \\
\hline $\begin{array}{l}\text { Changes } \\
\text { sources }\end{array}$ & $\begin{array}{l}\text { Deliver } \\
\text { grade }\end{array}$ & $\begin{array}{l}\text { yield } \\
\text { (gram in the } \\
\text { bush unit) }\end{array}$ & $\begin{array}{l}\text { Weight of } 100 \\
\text { seeds (gram) }\end{array}$ & $\begin{array}{l}\text { Numbers of } \\
\text { sheet in a bush }\end{array}$ & $\begin{array}{l}\text { Numbers of } \\
\text { the seeds in } \\
\text { the sheath }\end{array}$ \\
\hline Type & 3 & $2044 / 42499^{\star *}$ & $1102 / 862889^{* *}$ & $76 / 85000^{* *}$ & $68 / 46481^{* \star}$ \\
\hline Fertilizer & 14 & $1064 / 84405^{\star *}$ & $28 / 882008^{\text {ns }}$ & $34 / 25556^{* *}$ & $41 / 45794^{* *}$ \\
\hline Treatment & 42 & $52 / 02815^{\star *}$ & $20 / 239437^{\text {ns }}$ & $5 / 33810^{\text {ns }}$ & $27 / 64735^{\text {ns }}$ \\
\hline $\begin{array}{l}\text { Type * Fertilizer } \\
\text { Treatment } \\
\text { Error }\end{array}$ & 120 & & & & \\
\hline C.V (percent) & & $7 / 63$ & 9/04 & $4 / 38$ & $4 / 40$ \\
\hline
\end{tabular}

Comparison of the yield averages of spotted beans types shows that there is meaningful difference between types from this property viewpoint. Talash and Local types have the highest yield and difference of these two types with other types was meaningful (figure 1).

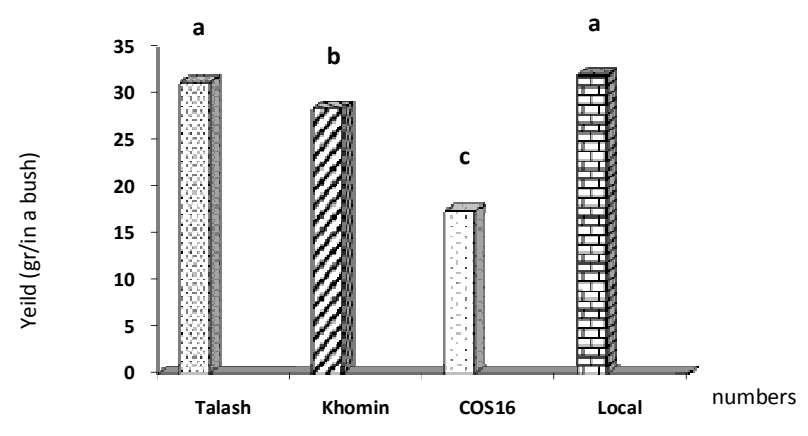

Figure 1: The effect of spotted bean types on the seed yield.

It seems that exceeding the yield of Talash and Local beans type is because of the mote Production of sheath numbers and the seeds in the sheath in comparison to khomein and COS 16. Khomein and COS 16 are among the types that are sensitive to iron lack in calcareous soils condition, so they show the lowest yield. The some results are proved by Godsey et al. (2003). The effect of sources and various kinds of iron fertilizer consumption on the seed yield amount was meaningful (figure 2). 


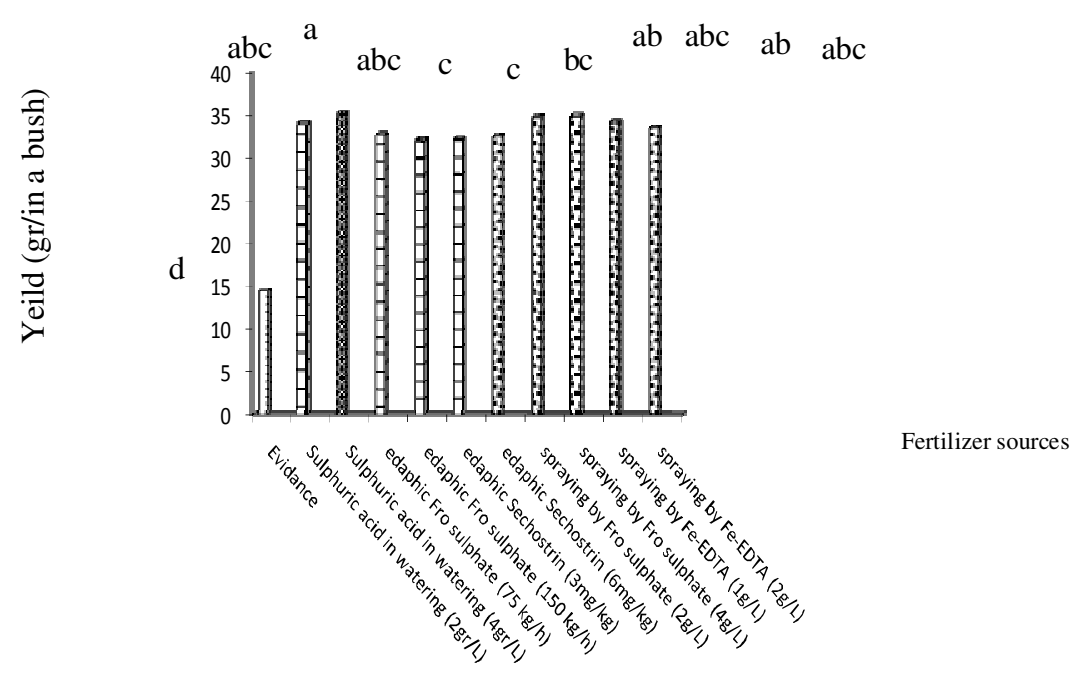

Figure 2: The effect of various fertilizers on the seed yield.

The most amount of the seed yield relates to treatment of sulphoric acid in irrigation water $(4 \mathrm{~g} / \mathrm{L})$ and the lowest amount relates to evidence treatment. In calcareous soils, elements accessibility increases by the reduction of soil $\mathrm{pH}$ - Acidizing of the watering is a suitable way for reducing soil $\mathrm{pH}$ (Donald and Billore, 2007). Acidifying the irrigation water improves the uniformity of $\mathrm{pH}$ in field and enhances the early establishment and growth of the plants (Patricia et al., 2009). Patrisia et al. (2009) reported that the yield of agriculture products increases by reduction of soil pH in the calcareous soils on the biotypes of chickpea which causes increase in yield. Kari et al. (2004) studied the edaphic and phyline effect of Fe- EDTA on the barley in calcareous soils and the result of their study showed that edaphic and phyline application of Fe- EDTA Khomein and Local type beans have higher average range than the other types from the numbers of 100 seeds (figure 3 ).

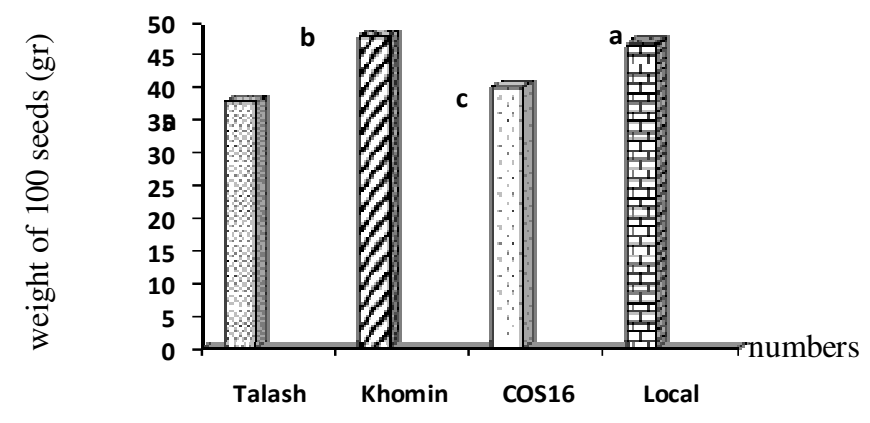

Figure 3: The main effect of pinto bean on the weight of 100 seeds.

Weight of 100 seeds is one of the efficient factors on the Grains seeds and relates to efficiency of photosynthesis organs and carbon oscillation during the filling of the considered seed. Morgan et al. (2002) reported that biotypes of bean differ greatly with each other regarding to weight of 100 seeds. There was hot meaningful difference between various fertilizer sources and the evidence, for the weight of 100 seeds. Infact, application of various fertilizer sources doesn't have effect on the weight of 100 seeds and it seems this property is under the influence of genetic factors of the plant. Weight of 100 seeds showed positive and meaningful conjunction. Positive conjunction between the weight of 100 seeds and seed yield reveals that the seeds yield increases by increasing the weight of 100 seeds. Talash type possesses the highest average from the number of sheath in a bush and number of the seeds in the sheath viewpoint, and it has a meaningful difference regarding to these properties with other types (figure4). 


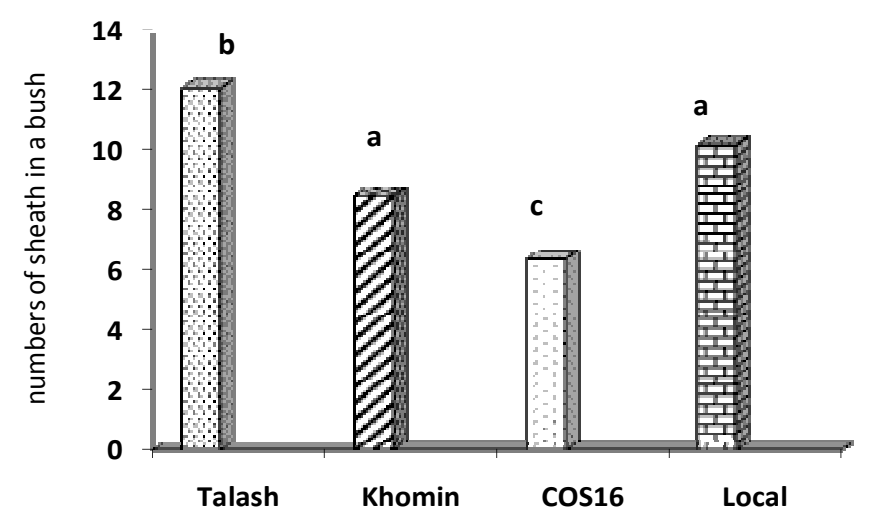

Figure 4: The main effect of spotted bean on numbers sheath in a bush.

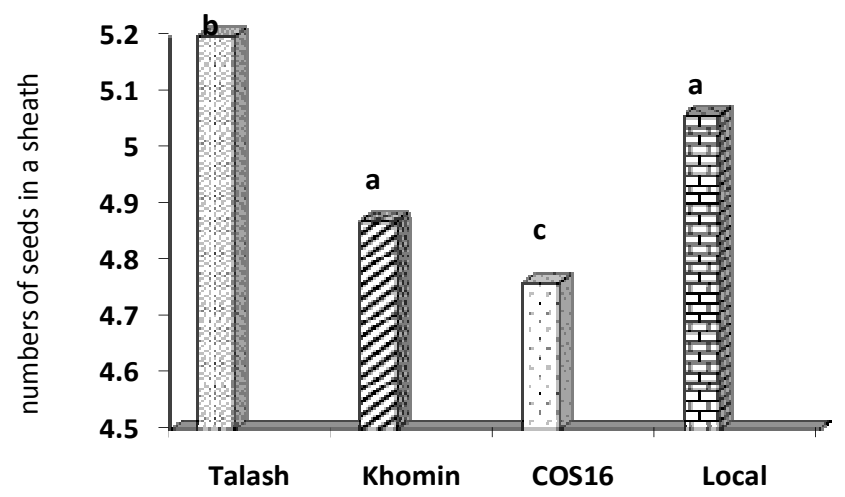

Figure 5: The main effect of spotted bean on numbers of seed in a sheath.

Grain number in each spike is one of the most important yield components; it has the (Ghorbani and Hamid, 2009) most effect on yield (Mahmoudi et al., 2013). From the property of numbers of the sheath in a bush, treatment of sulphoric acid in watering by the amount of $4 \mathrm{~g} / \mathrm{l}$ has higher average than the other fertilizer sources (figure 6).

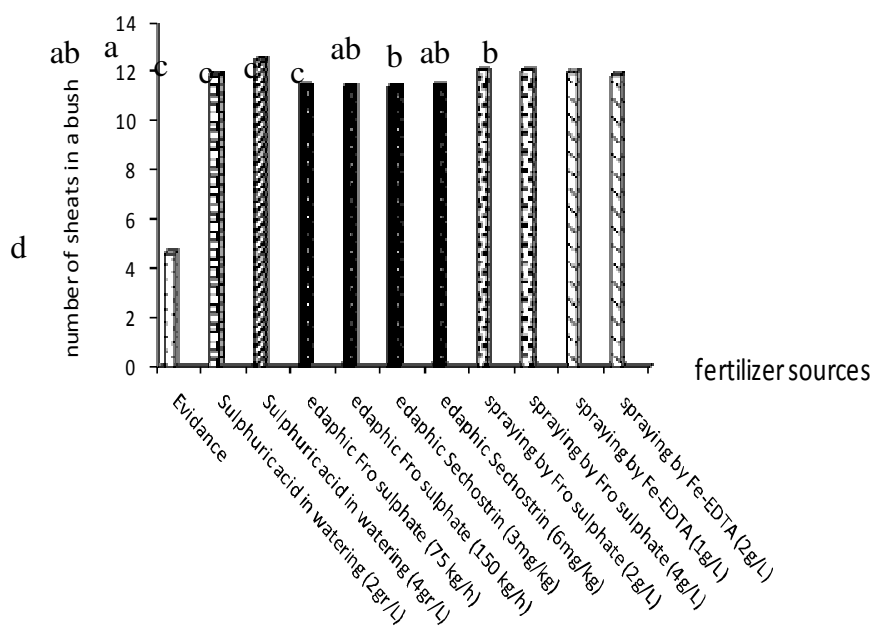

Figure 6: The effect of various fertilizer sources on the numbers of sheathes in a bush. 
In the study which is accomplished on the effect of watering iterates and application of acid in watering for the bean, it is observed that negative specifications (Dry weight, height, number of the branches) and non-negative (numbers of in a bush), increased by the extra iterates of watering and acid application in watering (Jendy et al, 1995). Treatments of spraying by sulphate and Fe-EDTA had no meaningful difference regarding to the average of the sheath numbers in a bush and both treatments have caused the increase in the sheath numbers but they have lower average in comparison to the treatment of acid consumption in the watering. Lingenfelser et al (2005) in a research by removing the chlorosis due to the iron back and spraying Ferrous sulfate reported the yield increase with the increase of seed amount. Treatments of Ferrous sulfate and Fe-EDDHA have lower average than the spraying treatment but both of them cause increase in the number of sheath in a bush toward the evidence ratio. Wiersma (2003) reported the increase of soybean yield due to the increase in the seed numbers in a bush, using Fe-EDDHA in various amounts.

sulphoric Acid in irrigation water by the ratio of $(4 \mathrm{~g} / \mathrm{L})$ has a higher level of average than the other sources from the property of numbers of seed in the sheath, and there is a meaningful difference between the various fertilizer source (figure 7).

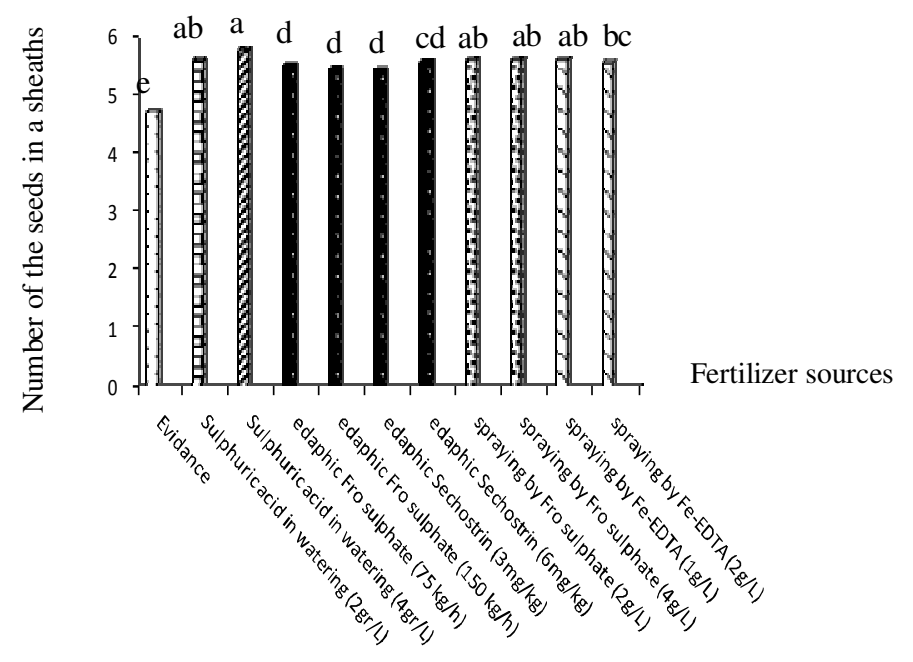

Figure 7: The effect of various fertilizer sources on the numbers of seeds in a sheath.

By considering that the numbers of seeds in a sheath is one of the related factors to the growth, so any factor which increases the yield, in effects increases the growth. Ferrous sulfate and Fe-EDTA treatments in spraying form have lower average than the acid consumption in watering treatment but they caused increase in the seeds numbers of a sheath comparing to evidence. Hegazy et al. (1993) observe that maximum yield of the bean seed is obtained by spaying ferrous sulfate, zinc, and manganese with \%2 densities after plant blooming.

\section{Chemical Element of the leave}

The effect of various types and ways of iron fertilizer consumption were also meaningful on the iron, manganese, zinc and copper elements of the leave in \%1 probability level (table 2).

Table 2 continuation: Results of variance analysis of the iron various treatments ' effect in the spotted bean and on the chemical compound of the leave

\begin{tabular}{|c|c|c|c|c|c|}
\hline $\begin{array}{l}\text { Changes } \\
\text { sources }\end{array}$ & $\begin{array}{l}\text { Deliver } \\
\text { grade }\end{array}$ & Leaf's iron & $\begin{array}{l}\text { Leaf's } \\
\text { manganese }\end{array}$ & Leaf's zinc & Leaf's copper \\
\hline Type & 3 & $5835 / 368^{\star \star}$ & $0 / 509259^{\text {ns }}$ & $8 / 95062^{\text {ns }}$ & $7 / 710908^{\text {ns }}$ \\
\hline Fertilizer Treatment & 14 & $587192 / 942^{* *}$ & $556 / 166448^{* *}$ & $1282 / 80475^{\star *}$ & $434 / 226364^{* *}$ \\
\hline $\begin{array}{l}\text { Type * } \\
\text { Treatment } \\
\text { Error }\end{array}$ & $\begin{array}{l}42 \\
120\end{array}$ & $2723 / 032^{* *}$ & $2 / 294974^{* *}$ & $15 / 12346^{* *}$ & $4 / 558350^{* *}$ \\
\hline C.V (percent) & & $0 / 78$ & $7 / 75$ & $4 / 94$ & $6 / 07$ \\
\hline
\end{tabular}


There was meaningful difference between the numbers compared to the amount of leaf iron and Talash type has the higher- level average than the others (figure 8).

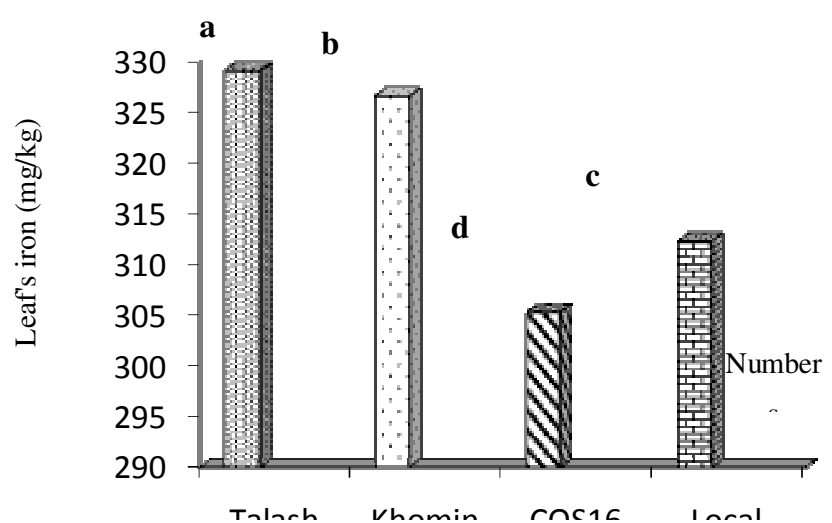

Figure 8: The main effect of spotted bean numbers on the amount of leaf's iron.

Raising the iron amount of the leave in Talash Type compared to other types shows the capability and ability of reduction of Iron (3) to Iron (2) in its roots. The results coincided with Godsey et al. (2003) report that edaphic factors and radical system variety are effective for absorption of the elements by the biotypes. The same results are also proved by Vempati et al. (1988). The effect of applied fertilizer sources caused iron absorption. Spraying with Fe- EDTA up to $(1 \mathrm{~g} / \mathrm{L})$ had the highest average of leafs iron, and there was meaningful differences between the fertilizer sources in this regard (figure 9).

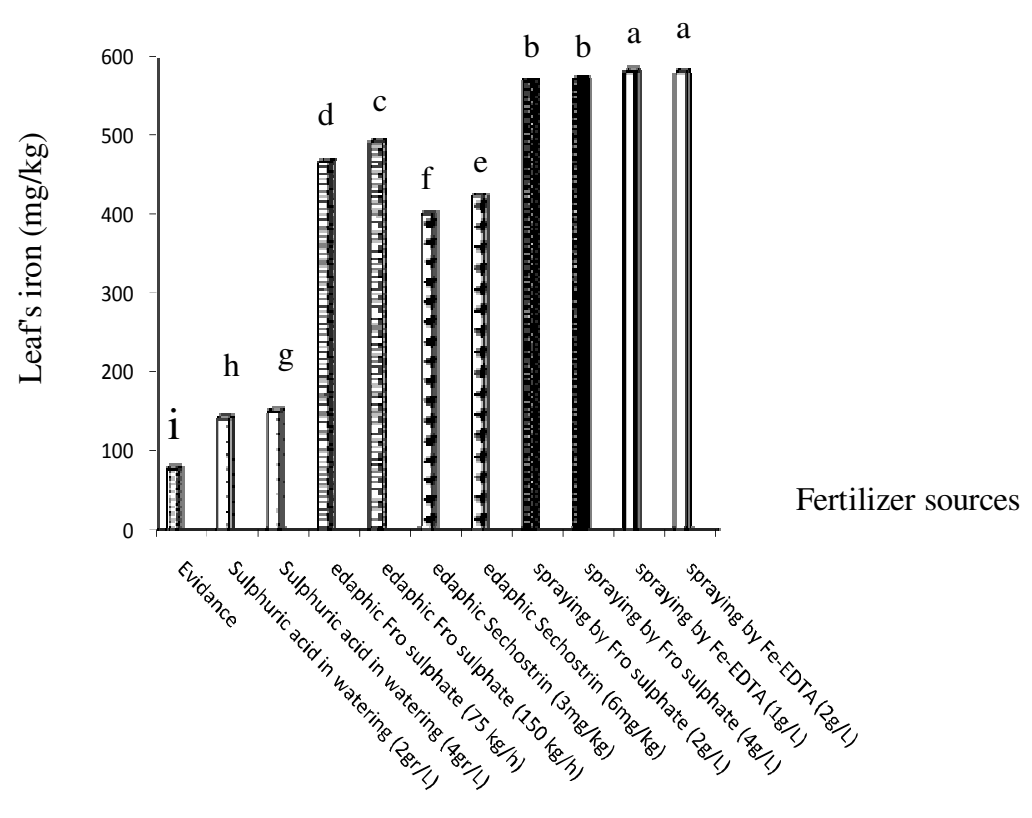

Figure 9: The effect of various fertilizer sources on the leaf's iron.

The application of Fe- EDTA increased young plant leaf iron concentrations by $10 \%$ when compared to threeyear- old plants treated with and without iron chelates (Natt, 1992). Spraying iron fertilizers create higher density of iron compared to its edaphic usage. Because of the present of calcium carbonate in the soil, capability of nutrient elements specially iron reduces and causes chlorosis on the leaves. Application of iron fertilizer sources by spraying is more effective for rapid iron chlorosis and its absorption through leaves than its edaphic application (Tisdale et al., 1984) iron sulfate added to calcareous soils which quickly reacts with $\mathrm{CaCO}_{3}$ to form Fe oxides that are less available for plant uptake (Godsey et al., 2003). Lack of less application element especially iron is 
harmful for the function and quality of agriculture products (Ghorbani and Hamid, 2009) although soil application of iron sulphate is not recommended, especially in calcareous soils; the data revealed that it could be used successfully as a foliar spray (Modaihsh et al., 1996). Han et al. (1994) Reports foliar application of Fe- chelates was shown to be more efficient than soil application because of the direct uptake of Fe by the plant through cuticle pores from the leaf surface. Foliar application can correct Fe chlorosis in bean, sorghum, peanut, rice and other fruit crops. Using optimal foliar Fe fertilization application in a field experiment, Fe content of rice was signification iv a field experiment, Fe content of rice was significantly increased by $37.1 \%$, compared with no foliar application, without affecting grain yields, protein and ash content of rice produced. Study of in a limy soil, investigated the effect of iron fertilizer sources on the granular broom corn at field conditions. The results demonstrated that spraying Fe-EDTA and iron sulphate caused increase in the leaves iron. Erdal (2004) by the application of $\mathrm{Fe}$ - EDTA and $\mathrm{FeSO}_{4}$ in spraying from the strawberry at three stages revealed that both iron sources caused increase in the iron density at the leaves. Roomizadeh and karimian (1996) reported that iron application in Fe- EDDHA from, in all tested calcareous soil meaningful increased the iron density in soybean. Lowering the $\mathrm{pH}$ of the soil often improves availability on iron, and other micronutrients on calcareous soils. Acidifying water also helps to improve water penetration and alleviates some of the stress of soda soils. Horneck et al. (2004) by acidizing the soils found that dissolubility and absorption of less application elements such as iron reduce by reduction of $\mathrm{pH}$. There was no meaningful between the numbers regarding to the amounts of leaves geneses, zinc and copper. Treatment of sulphoric acid in irrigation water had higher level of leaf manganese average compared to evidence cure and the other fertilizer sources. Results showed that sulphoric acid application in watering caused increase in the density of leaves manganese while the application of iron sources whether in soil or spray form caused reduction in the leaves manganese density (figure 10).

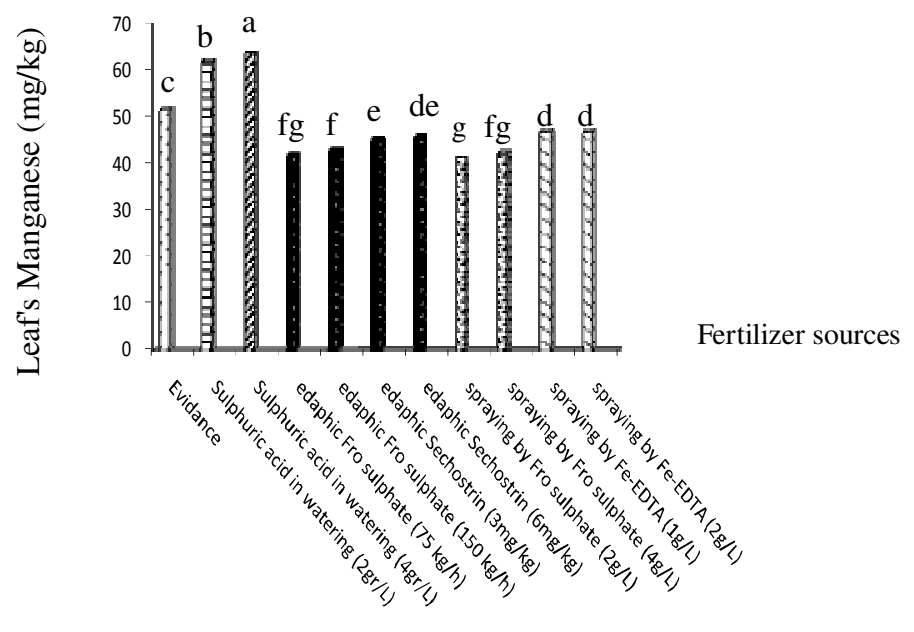

Figure10: The effect of various fertilizer sources on the leaf's manganese.

In calcareous soils dissolubility and access to less application elements reduced. One of the reduction ways of $\mathrm{pH}$ is applying acid in watering which causes dissolubility of less application elements (Stevens and Poorte, 2006). Factors which influence the manganese dissolubility, oxidation and restoration conditions of soil, determine the manganese absorbance capability for plants. Soil pH is among the most important factors. Reduction of soil pH causes increase in manganese compounds dissolubility which leads to the increase in its absorbance capability. Donald and Billore (2007) reported that acidizing the water was a costly and time consuming process with soil pH reduction and less application element absorption increase. Kalbasi et al. (1988) by the study of sulphur application in manganese absorption at three plant in clouding maize, surgme and soybean in the same argillaceous soil with $40 \%$ lime and in the field test showed that sulphur consumption caused a meaningful reduction $\mathrm{pH}$ and Bicarbonate density of soil and increased the absorption manganese of the plant. Reduction in manganese absorption due to the iron fertilizer application may be contributed to the same places of iron and manganese absorbance on the root level (Schenkedeld, 2008). Probably iron and manganese compete in the absorption processes and its transfer from the root to the air organs (Malakouti, 2000) and this competition causes the reduction of manganese density in all treatments that contain iron fertilizer except for the sulphoric acid in watering cure, compared to the evidence. Ghasemi et al. (2008) by using the various iron sources on the soybean found that iron application in soil form caused reduction of manganese in the root and leaves and which of course the result showed that the percent of manganese reduction differs between the varieties. Karaman et al. (1997) through their researches suggested that application of various iron sources 
caused manganese reduction in the leaves. Luccena et al. (1992) demonstrated that, although iron schostrin is the most suitable iron fertilizer in calcareous soil, but it should be noted that much application of this application could lead to incidence of manganese loss in soybean. Roomizadeh and karimian (1996) also reported a reduction of manganese density due to the iron application. The highest level of density average on the leaf related to sulphuric acid in watering $(2 \mathrm{~g} / \mathrm{L})$ which caused increase of zinc absorption on the plant compared to evidence, but other fertilizer source had a reduction of zinc absorption regarding to evidence (figure 11).

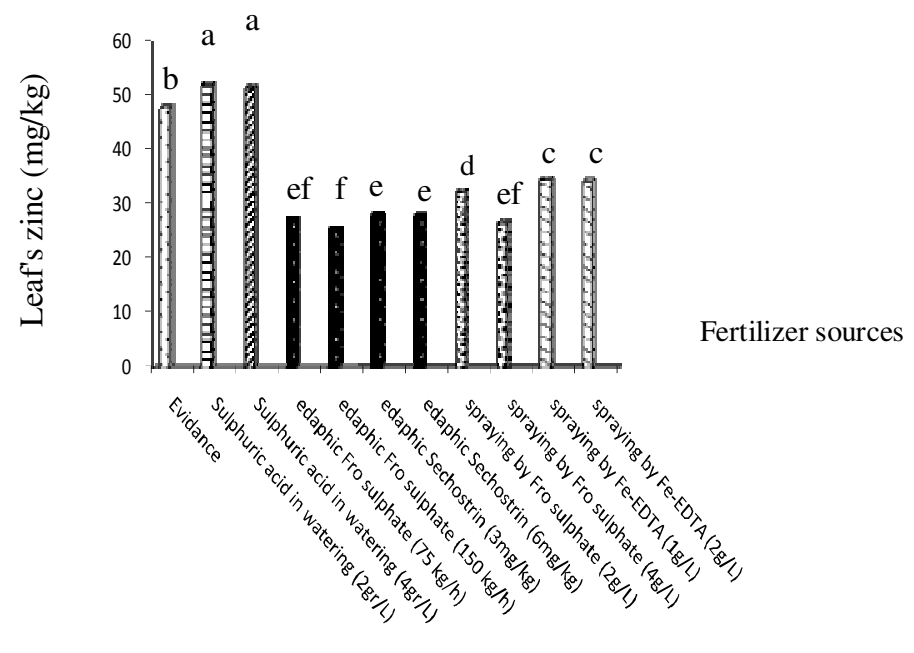

figure11: The effect of various fertilizer sources on the leaf's zinc.

Presence of sulphoric acid in soil caused the reduction of soil pH and the soil absorbance of zinc to increase (William and keatinge, 2006). Bioavailability of all micronutrients is significantly affected by soil $\mathrm{pH}$, decreasing with increasing soil $\mathrm{pH}$. The activity of $\mathrm{Fe}, \mathrm{Mn}, \mathrm{Cu}$ and $\mathrm{Zn}$ decreases for each unit increase in soil $\mathrm{pH}$. As illustrated in (figure 11) it is observed that various iron sources caused zinc reduction on the leaves. The reason of zinc density reduction due to the various iron sources consumption could be the result of iron and zinc competition in absorption by the plant. Negative interaction between iron and zinc could be a reason for zinc density reduction due to the iron consumption. Negative interaction between iron and zinc is reported by many researchers including Malakouti et al. (2000). Antagonism between Fe and $\mathrm{Zn}$ is well known. Previous studies have shown that $\mathrm{Zn}$ interfered with Fe uptake and translocation, whereas Fe interfered with $\mathrm{Zn}$ translocation, but only when Zn concentrations were high (Alloway, 2008). There are three possible mechanisms for this antagonism. First, there could be competition between $\mathrm{Zn}^{2+}$ and $\mathrm{Fe}^{2+}$ during uptake. Second, there could be interference in the chelation process during $\mathrm{Fe}$ uptake and translocation (kabata-Pendias, 2001). Third, there could be competitive inhibition between $\mathrm{Zn}$ and Fe during unloading in the xylem (Alloway, 2008). The highest level average of leaf's copper density related to sulphoric acid consumption cure in watering up to $2 \mathrm{~g} / \mathrm{L}$. sulphoric acid treatment in irrigation caused increase of copper amount of leaves while other fertilizer sources caused the reduction of the copper amount of leaves as compared to evidence (figure 12). 
a a

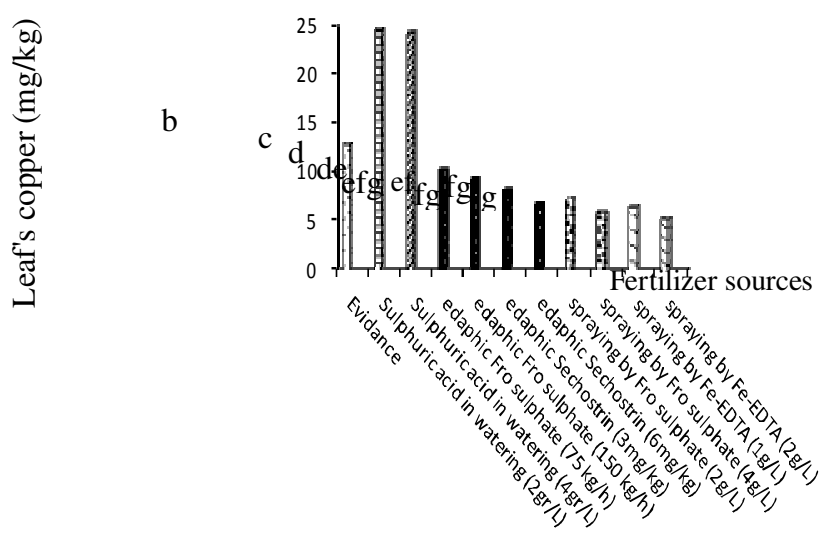

Figure 12: The effect of various fertilizer sources on the leaf's copper.

By the presence of sulphoric acid in soil acidic small points are created and it provides a better condition for analysis and more and quick absorption of iron, zinc, copper and manganese (Khadem and Rashed, 2007). Cetia et al. (2002) reported that acid application in watering is effective in dissolubility of less application elements. Togay et al. (2008) studied the effect of various acidic materials on barley yield elements in Turkey and the results of their researches show that the copper content of leaves are influence by sulphur application. As illustrated in (figure 12) it is observed that various iron fertilizer sources reduced copper absorption, both in spray and soil consumption. Leave's copper reduction due to the iron application is probably because of iron and copper competition for capturing the same spotted and places in carriers at the absorption process from root to air organs. Iron supply significantly reduced wheat $\mathrm{Cu}$ concentrations. Iron supply generally reduced wheat $\mathrm{Mn}$ concentrations, especially in stems leaves a number of studies have reported antagonism between Fe other cationic micronutrients, especially Mn (Izaguirre- Mayoral and Sinclair, 2005; Ghasemi- Fasaei and Ronaghi, 2008). Pais and Benten (1997) reported that two elements of iron and copper have negative interaction. Basar and Ozgumus (1999) declared that there is a negative relation between iron and manganese density and the zinc and copper on the beach trees. Danshnia et al. (1988) reported that much application of Fe-EDDHA in some of the calcareous soils of southern Iran may lead to the loss of lees application elements like zinc, manganese and copper. Zakaria et al. (2006) reported that Ferrous sulfate application in spray form coursed reduction of the copper density in the leaves.

\section{CONCLUSION}

Micronutrient deficiency limits plant growth and affects crop yield, especially in calcareous soil. The results revealed that the application of balanced fertilization significantly increased grain yield. The application of micronutrient fertilizers to micronutrient- deficient soils is associated with improved yield and crop quality for cereals, corn, beans, forages, and oil seeds (Malakouti and Tehrani, 2005; Malakouti, 2007). The correction of iron chlorosis in trees grown on calcareous soils is normally achieved by the application of Fe (III)-chelates such as iron ethylene die amino die hydroxyl phenyl acetate (Fe-EDDHA) to the soil. In calcareous soils like our soils in Zanjan province, there is low amounts a plant available $\mathrm{Fe}$, despite the large amounts of total $\mathrm{Fe}$ in them because of the effect of high $\mathrm{pH}$ on reducing Fe availability and so, iron uptake by plant becomes low (Saleh, 2008). Regarding to results obtained of the considered tests, Local number is recommended as a substitution of business numbers from the various viewpoints such as yield (31/959g in a bush unit) bean culturing in the field is a accomplished by using the numbers which are among stolen types regarding to growth types and their mechanization yield is hot possible, but COS16 type is half- standing and can used in mechanization yield. Acid consumption in watering as agronomic effort can be used for removing of iron loss in the bean and also for increasing of other less application and phosphorus elements absorption. Pan and Jackson (2011) reported that acidic application in watering was effective in less application elements absorption. The reports of Talash type to acid consumption in watering was more than the other types, so that it caused the highest level of yield in this type. Spraying with fertilizers contained iron, chlorosis due to the lime and Fe-EDTA was more effective other than fertilizers contained iron. The same results are obtained by Fernandez (2007). 


\section{REFERECES}

Alloway, B. J. (2008). Zinc in soils and crop nutrition. IZA and IFA Brussels press, France.

Basar, V. and Ozgumus, N. (1999). Foliar Iron Fertilization of Peach (Prunes Persian (L.). Batsch): Effects of Iron compounds. Plant Soil. 289:239-252.

Cetia, G. and A. K. Dwiredi. (2002). Interaction sulphoric acid fertilizer on yield and nutrient composition. FABIS Newsletter.27:13-15.

Cakmak, I. (2008). Enrichment of cereal grains with zinc: Agronomic or genetic biofortication. Plant Soil.302:1-17.

Danshnia, A., M. Mafteon, N. Karimian, A. R. sepaskhah, Y. Mehdi zadeh, A. shahrokhnia and H. Rastegar. (1988). Effect of nitrogen and iron on yield and quality of drip- irrigated tangerine. Soil \& Water Research. Ministry of Agric. 1366. Progress, PP. 65.68. (in Farsi).

Donald, S. K., and S.D. billore. (2007). Effect of level and source of sulphur on symbiotic and biometrical parameters of soybean. Indian Agricultural Sciences.65:140-144.

Emadi, M., Baghernejad, M., Bahmanyar, M., \& Morovvat, A. (2012). Changes in soil inorganic phosphorous pools along a precipitation gradient in northern Iran. International Journal Of Forest, Soil And Erosion (IJFSE), 2(3), 143-147.

Erdal, M. (2004). Correction of iron deficiency in strawberry by foliar sprays of Fe-EDTA. Journal of Plant Nutrition. 27: 51-53.

Fernandez, A., P. Garcia - Lavina, C. Fidalgo, J. Abadia and A. Abadia.( 2007). Foliar fertilization to control iron chlorosis in pear (Pyres communes L.). Plant and Soil 263: 5-15.

Goos, R.J., and B. E. Johnson. (2000).A comparison of three methods for reducing iron deficiency chlorosis in soybean. Journal of Agronomy.92:1135-1139.

Godsey C B,Schmidt J P, Schlegel A J,Taylor R K, Thompson C R,Gehl R J.(2003).Correcting iron deficiency in corn with seed row-applied iron sulfate. Journal of Agronomy.95:160-166.

Ghasemi, B. and A. Ronaghi. (2008).Interaction of iron with copper, zinc and manganese in wheat as affected by iron and manganese in calcareous soil. Journal of Plant Nutrition.31:839-848.

Ghorbani, A. and M. Hamid. (2009). Effect of foliar application of micronutrients on yield characteristics of wheat grown on calcareous soil. Journal of Agriculture.460-465.

Horneck, Y. and K. abak. (2004). Inheritance of to clearance to leaf iron deficiency chlorosis in tomato. Euphytica. 139: 51-57.

Han, C Li.C, Li R, way Q, wum, xiao c.(1994).Technical approach to application of iron fertilization on soybean. Oil Crop of China .16:43-45(in Chinese).

Hegazy, M. H., D. N. Abadi and S. A. Genaidy. (1993). Effects of some micronutrients and methods of application and rhyzobium inoculation of faba bean. Egyptian Journal of Agriculture. Research. 71: 21-33.

Izaguirre-Mayoral, M.L., and T.R. Sinclair.(2005).Soybean genotypic difference in growth, nutrient accumulation and ultra structure in response to manganese and iron supply in solution culture. Plant Soil.96:149-158.

Javanmiri Pour, M., Jahani, A., \& Marvi Mohadjer, M. (2013). Effects of livestock grazing on vegetation in relation to distance from corral in Caspian forest north of Iran. Research Journal Of Forest And Environmental Protection, 1(1), 1-11.

Jendy, E. N., S. S. S. EL - Raies and M. A. A. Reheem. (1995). Effect of number of irrigations and sulphuric acid application on board bean growth and yield. Egyptian Journal of Soil Science, 35(3): 379-393.

Khan, H.R., G.k.M. Donald and Z. Rengel. (2003).Zn fertilization improves water use efficiency .grain yield and seed Zn content in chickpea. Plant Soil.249:389-400.

Karkosh, A.E., S.k. Walker, and J.J. Simons. (1988). Seed treatments for control of iron deficiency chlorosis of soybean. Crop Science. 28:369-370.

Karaman, R. E., K. Soerensen, V.D. Jolley and J. C. Brown.( 1997). Soil iron deficiency. Journal of Soil Science. 130: 225-230.

Kalbasi, M., F. Filsoof and Y. Reazi - Nejad. (1988). Effect of sulfur treatment on yield and uptake of Zn, Fe and Mn by corn, sorghum and soybean, Journal of Plant Nutrition, 11(6-11): 1353-136.

Kari, V. Y., A. Jaakkala and R. Aksela. (2004). Effects of Fe compounds on nutrient uptake by plants grown in sand and media with different $\mathrm{pH}$. Department of Applied Chemistry and Microbiology, FIN- 00014 University of Helsinki, Finland.

Khadem, D. and J. Rashed. (2007).Soil and crop management strategies to prevent iron deficiency in crops. Plant Soil.339:83-95.

Lewis, D. C. and J.D. Mcfarland. (1986). Effect of foliar applied manganese on the growth of safflower and the diagnosis of manganese deficiency by plant tissue and seed analysis. Journal of Agriculture Researcher.

Luccena, J. J., M. manzanaves and A. garate. (1992). A test to evaluate the efficiency of commercial Fe chalets. Journal of Plant Nutrition, 15: $1553-15556$.

Lingenfelser, J. E., W. T. Schapaugh, J. P. Schmidt and J. J. Higgins. (2005). Comparison of genotype and cultural practices to control iron defiance chlorosis in soybean. Soil Science Plant. 36: 1047 - 1062.

Lu kow, O.M. and P. B. E. Mcvetty. (1991). Effect of cultivar and environment on quality characteristics of spring wheat. American Association of Cereal Chemists, Inc. 68(6):598-600.

Mahmoudi, J., Zareian, F., \& Javadi, M. (2013). Study of Grazing and Exclusion Effects on Soil characteristic (Case study: Viseh Valley, Iran). International Journal Of Forest, Soil And Erosion (IJFSE), 3(2), 60-63. 
Malakouti, M. J. (2007). Zinc is a neglected element in the life cycle of plant: A review. Middle East .Rus. Journal of plant Science and Biotechnology.18:1-12.

Malakouti, M. J. and M. M. Tehrani. (2005). Effects of micronutrient on the yield and quality of agricultural products: Micro nutrient with macro-effects. Terabit Madres university press. Tehran, Iran.p.445.

Malakouti, M. J. (2000).Balanced nutrition of wheat: An approach towards self -sufficiency and enhancement of national health.A compilation of papers. Ministry of Agricultuer,Karaj,Iran.p.544

Morghan, J. T., V. M. Son and T. Duong.( 2002). Iron accumulation in seed of common bean. Plant Soil. 246: 175 $-183$.

Natt, C. (1992). Effect of slow -release iron fertilizers on chlorosis in grape. Journal of Plant Nutrition.V.15.p.1891-1912.

Penas, E.J., R.A. wiese, R. W. Elmore, G.W. Hergert, and R.S. Moomaw. (1990).Soybean chlorosis studies on high $\mathrm{pH}$ bottom land soils. Uric. Nebraska Inst. Journal of Agriculture Research.

Pais, I. and J. Benton Jones. (1997). the hands boo of trace elements. St Lucie Press. 217pp.

Pan, D. and T. Jackson. (2011). Effect of soil acidify and nitrogen on yield and elemental concentration of Bean. Journal of Soil Science. 107(5).740-744.

Patricia, M., H.Ali and T.Mahmood.(2009).Impact of nitrogen and sulfur application on growth and yield of chickpeas crop. Plant Soil.Vol.15, No.2.Pp. 153-157.

Roomizadeh, S. and N. Karimion. (1996). Manganese- iron relationship in soybean growth in calcareous soil. Journal of Plant Soil. 19:397 - 406.

Stevens, L. and V. Poorten. (2006). Relationships between soybean yield, soil PH and soil carbonate concentration. Journal of Agriculture.71:21-33.

Schenkereld, W. D.C., and R.D. Jcker. (2008). the effectiveness of soil-applied Fe-EDDHA treatments in preventing iron chlorosis in soybean as a function of the o, o-Fe-EDDHA content. Plant Soil.102:550-555.

Saleh, J. (2008). Yield and chemical composition of piarom data palm as affected by levels and methods of iron fertilization. Journal of Plant: 1735-6814.

Shadkami-Til, H. (2013a). Over-under ground Biomass characteristic of perennial Species (Sagoisorba minor) in northwest Iran (Till area of Shabestar). International Journal Of Scholarly Research Gate, 1(2), 9-14.

Shadkami-Til, H. (2013b). Under-over ground Biomass characteristic of perennial Species (Acanthophllum acerosum) in northwest Iran (Till area of shabestar). International Journal Of Scholarly Research Gate, 1(1), 4-8.

Shadkami-Til, H. (2013c). Under-over ground Biomass characteristic of perennial Species (Onobrychis melanotricha) in northwest Iran (Till area of shabestar). Research Journal Of Forest And Environmental Protection, 1(1), 12-16.

Soil Science Society of American.(1997). Glossary of soil science terms. SSSA .Madison WI.

Singh, A. L., Chowdhury, V., Karadia, V.G. and Zala, P.V. (1995). Effect of irrigation and iron sulphate fertilizers on the chlorosis, dry matter production yield and nutrients uptake by groundnut in calcareous soils. Journal of Aronomy.39:187-198.

Sarkar, D. B., Mandal. And M. C. Kundu. (2007).Increasing use efficiency of boron fertilizers by rescheduling the time and methods of application for crops in India. Plant Soil.301:77-85.

Sultana, N.T.,Ikeda and M.A. Kashem.(2001). Effect of foliar spray of nutrient solutions on photosynthesis, dry matter accumulation and yield in seawater-stressed rice.Environ.Exp.Bot.46:129-140.

Togay, Y. N., F. m. Cig and A. Esencelen. (2008). the effect of sulphuric acid application on nutrient composition, yield and some yield components of barley (Hoodlum vulgar). African Journal of Biotechnology. Vol. 7(18), pp. $3255-3260$.

Tisdale, S. L., W. L. Nelson and J. D. Beaton. (1984). Soil Fertility and fertilizers. 4the. Ed. Macmillan pub. Co. New York. 754p.

Vempati, R.K., Loeppert RH. (1988).Chemistry and mineralogy of Fe-containing oxides and layer silicates in relation to plant available iron. Journal of Plant Nutrition. 11:1557-1574.

Wissuwa, M.A., Ismail and R.D. G. raham. (2008).Rice grain zinc concentrations as affected by genotype native soil-zinc availability, and zinc fertilization. Plant Soil.306:37-48.

Wiersma, J.v. (2005). High rates of Fe-EDDHA and seed iron concentration suggest partial solutions to iron deficiency in soybean. Journal of Agronomy.97:924-934.

Wiersma, J. V. (2003). Iron acquisition of three soybean varieties grown at five seeding densities and five rates of Fe-EDDHA. Journal of Agronomy. 99: $1018-1028$.

William, M. and J. keatinge. (2006). Effect of sulfur and iron on the growth, yield concentration and uptake of $\mathrm{Cu}$, $\mathrm{Mn}$ and $\mathrm{Zn}$ in soybean. Journal of India.28:113-118.

Zakaria, S. M., S. A. Hafez, A. E. Basyony and A. E. E. Alkassas. (2006). Cottonseed, protein, oil yields and oil properties as affected by foliar application of potassium and a plant growth retardant. Word Journal Agricultural WSciences: 56-65. 